\title{
Classification and hierarchy in the discourse of wine: Émile Peynaud's The Taste of Wine
}

\section{Nigel Bruce}

\section{(2) OpenEdition}

Electronic version

URL: http://journals.openedition.org/asp/2376

DOI: $10.4000 /$ asp.2376

ISBN: 978-2-8218-0380-0

ISSN: 2108-6354

\section{Publisher}

Groupe d'étude et de recherche en anglais de spécialité

\section{Printed version}

Date of publication: 1 December 1999

Number of pages: 149-164

ISSN: 1246-8185

\section{Electronic reference}

Nigel Bruce, «Classification and hierarchy in the discourse of wine: Émile Peynaud's The Taste of Wine », ASp [Online], 23-26 | 1999, Online since 21 June 2011, connection on 30 April 2019. URL : http:// journals.openedition.org/asp/2376 ; DOI : 10.4000/asp.2376

This text was automatically generated on 30 April 2019.

Tous droits réservés 


\title{
Classification and hierarchy in the discourse of wine: Émile Peynaud's The Taste of Wine
}

\author{
Nigel Bruce
}

\section{Introduction: language, knowledge and taste}

1 This paper is written against a background of teaching English for academic and professional communication in a university setting. One of my teaching concerns is with the status of disciplinary knowledge, since a high proportion of my first-year students seem disposed to accept what they read in expert-authored textbooks as factual accounts of an objective world. I suggest that this perspective on knowledge is not one confined to adolescents studying in a foreign language, but one ingrained in the knowledge beliefs that pervade academia and society at large.

2 Conceptions of what constitutes valid knowledge range from clear-cut 'strong' explanations, bound up with ideas of observability and cause-effect relationships, to 'weaker' explanations in which judgement and reasoning play a more prominent part. It is simpler to assert the rectitude of a proposition or theory when subscribing to a belief in an objective reality, and when motivated by the need for a 'truthful' or correct account. I am interested in how a view of the world we inhabit as having an objective reality seems to encourage a classification of the component parts and participants in that world, and in how we use language to accord attributes to objects, people and, in this study, tastes.

3 In this paper I look at the use of language and construction of knowledge in a nonacademic field, one which embraces the business and culture surrounding the study, production, marketing, critique and enjoyment of a single product: wine. What makes this particular field interesting is the sheer variety of the discourses of wine that have emerged, and the complex social hierarchies, systems of classification, and compendious descriptive vocabulary that have evolved in those discourse communities concerned with 
the production, marketing, chemical analysis, reviewing and general appreciation of wine. I shall explore that aspect of wine which acts as an aesthetic and commercial focus for a range of communities, which has the widest reach, and which enthuses anyone with an interest in wine - the appreciation and description of its taste and smell. The appreciation of wine a priori would seem to involve only the senses and a language to communicate one's impressions. As with any field of discourse, debates have arisen over freedom of interpretation, divergence of opinion, and issues of exclusivity, elitism and pedantry.

Deborah Lupton reviews the literature on beliefs about taste, and the widely reported tendency for people to define "good taste" as a universal standard to which people can aspire (Gronow 1993: 292). In Bourdieu's terms, people's tastes in wine are the result of their acculturation, and signify their social position or the "cultural capital" (1984) they aspire to. Both our preferences for and our discourses on wine form part of our cultural capital, and, as with all other observable distinguishing marks like dress, hairstyle, jewellery, such classifying markers serve the purpose of hierarchical discrimination. People are aware that such fashion statements signify social position or cultural capital, and that a perceived 'lack' of good taste can brand someone as "bidoun" - without - and therefore inadmissible to the elite or inner circle.

5 I am also interested in the propensity to classify and label as a marker of worldview, an indicator of relationships constructed between language, knowledge and society. In an approach not unlike Bourdieu's, Lisa Ann Gurr (1987) applied an analysis of types of drink as identifiers of different classes. In her paper on Georges Simenon's construction of a dated but socially stratified Paris for his Maigret books, she writes:

Simenon's distinction between drinks and between classes is very clear. The haute bourgeoisie and the aristocracy are set apart from the petite bourgeoisie by their drinks. [...] Maigret himself has reached the petite bourgeoisie [...]. In the Maigret stories there is very little naming of wines, and no overt gourmet appreciation of wine. Maigret would consider [sic] the gourmet approach to wine upper-class and affected [...]. The bouquet, aroma or body of a wine is rarely mentioned. (221-225).

The text I look at in this paper seems almost to be written out of frustration with this kind of society, one that has distorted and undervalued the world that the writer holds in great regard. The text is Émile Peynaud's seminal and highly influential book, The Taste of Wine: The art and science of wine appreciation (1987).Peynaud writes: "The statement, "Tell me what you drink and I will tell you who you are" is still valid". He begins by being very direct about how his "hero" (wine) goes unsung in its own country, by his own countrymen (women rarely figure in the book):

If you (the "amateur" reader) are French, you are possibly an advocate of drinking in quantity with traditional Rabelaisian extravagance, but statistically you are not a connoisseur [...]. It is well known in the trade that as a Frenchman your general knowledge of wine is below average and that you are a provincial [sic] drinker. (1987: 10)

In this paper I shall try to seek less direct indicators of how Peynaud constructs the key motifs in his book - the tastes and smells of wine - and what perspectives his discourse reveals about issues like social classification, and the objective or subjective status of knowledge of the taste of wine. 


\section{Émile Peynaud: Constructing wine, its taste and its tasters}

8 The Taste of Wine is a text written by an acknowledged expert on wine, who can lay claim to a high degree of authority, by virtue of his professional - and professorial - standing in the field of wine. I try to look at the way such an expert, Émile Peynaud, writes about his field, how he constructs his subject, wine and its taste, and the classes of people who populate his world, both as an audience for the book, and as participants in the organic world of wine. I take the approach that more revealing than single rational statements will be the aggregate picture, gleaned from looking at how Peynaud tackles the diverse aspects of the subjects he tries to cover. I look particularly for shifts in modality according to whether he is talking about the properties and characteristics of people, tastes or wines, and how and where he places these in the sets of hierarchies and classifications he draws up throughout the book.

\section{Émile Peynaud}

9 Émile Peynaud is Professor Emeritus of the Bordeaux Institute of Oenology. His Connaissance et travail du vin (1971) is an acknowledge classic text. The entry in the recent Oxford Companion to Wine (1994) describes Peynaud as having had "a profound and worldwide impact in wine-making and wine appreciation", and lists his achievements as a taster, scientist, teacher and consultant to winemakers.

The choice of Peynaud's text was influenced by the key role he ascribes to tasting in the whole wine-making process. His is far more than an interest in the ultimate pleasures of consumption. He is acknowledged as the oenologist who made taste the arbiter in winemaking decisions in the Bordeaux region. He says in the Foreword to The Taste of Wine:

I am not sure whether I have contributed most by making tasting an introduction

to oenology, or oenology an introduction to tasting (1987: 12).

11 I shall look in particular at Peynaud's rhetoric of the civilising character of wine, how he characterises the audience he has targeted, and how he constructs tasting knowledge, the properties of taste, and the expectations and aspirations of his audience to have access to that knowledge and ability.

\section{The civilising properties of wine}

12 Peynaud approaches wine with reverence and his book has a proselytising quality, attributing to wine a 'civilising' role. The theme of civilisation runs through the book, with wine presented at times as emblematic of the more desirable traits of western European culture. Here are some of Peynaud's comments about the 'civilising' properties of wine:

Wine develops as does our civilisation, primarily in terms of taste but also in terms of technology. (230)

13 At times we detect dynastic and imperials overtones to Peynaud's ambitions for the heightened appreciation of wine:

In the end for us wine lovers is that the civilisation of wine survives (231)

the civilising power of wine is conquering the world. (233) 

"indifferent to the pleasures of taste or smell", but a category that accounts for the consumption of the vast majority of French wines, and which is hence responsible for the mediocre quality of that wine. The next category of "false fine wine" allows Peynaud to characterise the pretentious "label" drinker:

[...] often people who have picked up a limited and hazy knowledge of wine [...] with a well-known label in front of him our spurious connoisseur decides that the taste and bouquet are what he likes [...]. He mistakes oxidised for age, ethyl acetate for 
bouquet and acid for full body. Were it not for his ignorance he would be an appreciative gourmet. (90) meanings. (161)

Coste's third category comprises "good wines": "well balanced, straightforward but attractive and easy to drink". In other words, while damned with faint praise, for Peynaud they provide a match for "the gourmand" - in the best sense - "for they regard wine as a real but uncomplicated pleasure [...]. They just drink it with pleasure and know why they like it" (91).

21 Finally, at the top of the hierarchy, comes the category of "fine wines": "wines as unique and flawless as a work of art". These are wines

for the informed amateur, privileged gourmet, erudite epicure; and drinking them involves an almost religious ritual [...]. The way to appreciate them is by repeated sipping and contemplation; great wines repay a constant re-examination, for they have as much to offer the mind as the senses. (91)

Peynaud cannot resist a swipe at the indiscriminate "soak", as he concludes this analysis with the following characterization of his various categories of "diner":

the gourmet considers what he chooses to eat as an intellectual pleasure, and the gourmand [...] enjoys everything that is good. The gastronome/epicure whose eating and drinking habits develop on a strictly scientific basis, would only be interested in the greatest of fine wines - monuments, museum pieces, classic masterpieces. And finally the glutton, staunch consumer of quantity, unable to control his tastes and inclinations, will simply soak up the mediocre [wine]. (91)

Strangely, although Peynaud deals with this in many other chapters, there is no mention here of the discussion of wine, the pleasure in that discussion, and the imperative to put the results of this reflection into words. In a chapter given over to addressing problems and errors, to categorising, eulogising and demonising, there seems to be no place for any discussion of the social negotiation of meanings or the possible plurality of those

\section{Wine tasting vocabulary: "elegant verbal juggling over a glass"}

Peynaud sets aside a whole chapter, and sections of other chapters, for an in-depth look at wine tasting vocabulary. He begins the chapter (9) by pointing to the importance of paying attention to the language of tasting, and admits:

in this subjective area the relationship between sensation and expression, between the word and the quality it describes, is not as straightforward as it is elsewhere

However, the problems for Peynaud lie not in the objective world of wine tastes and smells, but in our imperfect knowledge of the smells and tastes, and our "lack of vocabulary". Peynaud also points to the divergence in tasters' physical abilities and properties (oral acid balances, taste bud distribution and density, etc.), and the constant evolution of a wine's odours and flavours in the glass, such that any discussion of a wine is unlikely to find two people comparing exactly the same phenomena.

Peynaud warns against the indiscriminate use of the entire wine vocabulary available to us. He admits to there being, of the thousand-odd wine descriptors now available, around 470 words "which refer to taste characteristics" (163). Again, he succumbs to the temptation to classify, distinguishing three discourse communities: 
the professional taster's vocabulary, the amateur presenting a wine to guests at a dinner tasting, (and) [...] a wine journalist writing for the readers of a wine magazine. (163)

nd he goes on to discuss

several ways of talking about the taste of wine depending on circumstances, training and the taster's state of mind.

The expert: seeks clarity and precision above all in his expression. His style is strict and economical but his comments are reasoned; his conciseness is not due to a lack of imagination but to a choice of the most precise words, and in his reports he only uses terms with an accepted and agreed meaning. In spite of his skill his language should be simple and intelligible to all. Where technical terms are concerned ... he will ... refrain from defining smells by analogy with little known chemical substances. (163)

of "the more occasional taster" and "the informed amateur", Peynaud has much less to say. They

do not always express themselves precisely. Their vocabulary is more limited, their style more full of imagery but less precise. They speak in metaphors and allusions, and not always in the best of taste. The inventiveness of their vocabulary conceals its vagueness.

\section{Peynaud offers a straw of concession:}

Certain wines lend themselves well to such effusions, but not all: I have often admired the oratorical skill of presenters who can ease themselves out of a tight spot by distancing themselves sufficiently from their subject.

As we have seen, Peynaud acknowledges that in oenology, the senses of smell and taste are problematic extensions of observation. But while he admits to the difficulty of matching words to the "organoleptic" characteristics of smell and taste, he is caught between admitting to the elusiveness of language to describe taste - "it is impossible to describe a wine without simplifying and distorting its image" - and issuing warnings of the tendency to error, verbiage, and "unwarranted expressions". There is a clear acceptance that people will disagree over smells and tastes, yet while a wine's qualities may be ungraspable in their entirety, they remain there to be discovered like the physical world. Towards the end of the book he writes:

Objective qualities are said to be true, real and measurable, whereas subjective ones are unreal. But quality in a wine as perceived by tasting is a notion which is real enough. In effect there are greater and lesser degrees of objectivity when evaluating the quality of taste, depending on the quality of the taster [my italics]" (223)

Peynaud pursues this theme by looking at the objective accuracy and representativeness of the language itself. Here he attempts to wrestle with the "art" of language:

We know that underlying the words we use in speaking or writing there is more than the literal meaning. Some words are charged with ideas and images; that is the magic of a style of speech or writing which makes words say more than they actually mean (sic). There are some words which suggest and evoke more than they say, and others which one uses to say nothing at all. My career as a teacher has taught me that words or phrases only convey thoughts if these are expressed immediately they are conceived. Words spoken off the cuff, even if they are clumsy, are the most meaningful. (161)

Peynaud develops his theme of the use of words to "say more than they actually mean" when moving on to discuss how one solves this problem. In this passage he comes closest to a statement of his goal in writing this book: 
Habit and training eventually forge a link between impressions and the vocabulary one uses. Obviously it matters that the terms used signify the same for everybody, and they acquire precision as the taster acquires experience alongside other professionals ... It is important ... for tasters to have the same language and, in order to understand each other and to make themselves understood, to use the same words for the same perceptions(my italics). For these reasons the profession's vocabulary must be rationalized; a start has been made and I will be returning to the subject later. (162) Francaise, ensuring common usage and common understanding, a utopian ideal, perhaps, of a future "Académie du Langage du Vin". Peynaud is certainly steeped in the history of writing on wine, and in the development of terminology to describe wine over the centuries. He traces the development of the vocabulary of wine in France, suggesting that its growth from around sixty terms at the beginning of the $19^{\text {th }}$ century (Chaptal, 1807) to the "thousand or so" terms used today is testimony to an increase in the quality and complexity of wine, but also in our "knowledge" of wine:

the advance in oenological knowledge has meant the vocabulary can be filled out.

(168)

But he remains caught in the tension between the imaginary and the real:

A whole vocabulary has been created to describe these notions, imagined and yet real enough because everyone perceives them. (168)

\section{The metaphorical language of taste}

One has the impression that the language Peynaud has inherited to describe wine offers him an infuriating spectrum from very precise correlates of chemical, vegetal and mineral components to a penumbra of vague and idiosyncratic metaphorical constructions. In his chapter on the vocabulary of taste Peynaud isolates a section on "the metaphorical language of taste", his most interesting metalinguistic joust with the complexities of the language of taste.

Tasters' language is made up of precise terms for concrete sensations: sweetness, acidity, bitterness, the smell of ethyl acetate, for example; and for more subtle sensations it consists of imprecise, but conventional, terms which attempt to define a balance of flavours. In the first case the word fits the perception well and is intelligible. In the second case, by trying to clarify the blurred image of their sensations, tasters are led to juggle with words. (180)

Peynaud speaks positively of precise terms and concrete sensations, equating them with the scientific, with chemical compounds. When he turns to those more fuzzy and complex categories, subtle sensations and a balance of flavours, we need to "juggle with words". He elaborates:

To do this they have taken everyday vocabulary, and above all, they have applied words to wine in a metaphorical sense, as though discussing an object or a person, as though wine had shape and being. (180)

The 'lay' connotations of the everyday are clear, but interestingly Peynaud is later drawn into approvingly using physical and anthropomorphic metaphor to convey those meanings (see below). Continuing his 'lay' theme, Peynaud then offers a suggestion about groups having problems with certain uses of metaphor to describe wine which seem more applicable to the scientist than the 'layman': 
What fundamentally shocks and surprises the layman is the idealization and personification of wines. He finds it difficult to understand their being described as geometrical structures, as materials or as living beings. For in his comments a taster will attribute a shape and a texture to a wine, he will talk of its youth, its ageing, its defects and diseases, and he will bestow on it the rarest of human virtues: wine is honest, noble, loveable, generous, and so on. (180-1)

\section{Metaphors of hierarchy and morality}

As the rhetoric takes a moral turn here, we are reminded of the civilising theme of the book. Most revealingly - he seems unaware of the irony - Peynaud devotes a short paragraph to

expressions used to define a wine's place in an elite and hierarchical vinous 'society'. A great wine is presented as a nobleman. Classified wines (that is, wines which have class) described as noble, rich, and with breed, are distinguished from banal wines which are uncouth, common, vulgar, plebeian, poor, (etc.). There are also crus bourgeois and crus paysans. (181)

Peynaud's uncertainty as to what, if any, ethical position to take here is hinted at later when he says:

I agree that to attribute moral virtues to a wine is both inappropriate and ridiculous; but why can one not say of a wine without defects that it is sound, straightforward, clean, loyal, genuine, authentic, honest, pure, commercial? In any case, such vocabulary dates from the earliest commercial dealings. (181)

\section{Absent communities}

Strangely, given his identification of the wine producer as one of his 4 communities of reader, at no point in his discussion of the choice of such ethical attributes does Peynaud make the association between the wine and its producer. That the honesty described should reflect on the manner of its making, and the principles of the maker. But then there is an 'artisanale' characterisation to the producer, seen as early as the Foreword when Peynaud says half-apologetically:

Were it not for a pejorative ring in the context I would call vinification industrial in character, for it is essentially the processing of an agricultural product.

In case we miss the point - that currently too may wine producers remain in this industrial category - he adds:

The cellar-care of wine on the other hand is more of a craft; not, however, one of trial and error [unscientific!] for as a winemaker you will keep up with advances in oenology and in consequence your work will become yearly more exacting. (11)

\section{Peynaud concludes his address to this community of readers by exclaiming:}

How many mediocre wines would disappear from our shelves if only those who made them knew how to taste properly! (11)

The implications are clear: the wine producers as a group tend to be constructed as being ignorant of the art of tasting and therefore ripe for enlightenment by the oenologist. In most of the rest of the book, Peynaud goes to some lengths to persuade winemakers to change the way they approach the metier of winemaking - the chief of which is to learn to taste the wine they make.

4 Other communities that would seem to have a head start in detecting odours of wine cooks and, constituting the great majority of cooks, women - are also noticeably absent 
from Peynaud's discourse. Peynaud fails to mention these communities, either when discussing the huge range of wine odours, how to train tasters, or matching wine with food. Even when discussing the value of training one's sense of smell with the perfumiers of Grasse, he never ventures to suggest women might have an advantage over men. This cannot be because he eschews such comparisons - the whole book deals explicitly in hierarchies of aptitude.

\section{Returning to metaphor...}

Peynaud's opinion of the role of metaphor seems to be as a necessary evil, if used in moderation. He concludes this section:

There are circumstances where a little fantasy is appropriate ... But a word of advice: do not overdo it. Not all wines can stand exaggerated descriptions and not all audiences can put up with the absurd. (182)

At this point, as if to bring us back to earth, to his more favoured scientific terrain, Peynaud moves directly on to a discussion of "The influence of carbon dioxide on taste". Peynaud's discourse style seems from this point to take on a tone of greater certitude, as in this extract from his subsequent section on "The vocabulary of olfactory qualities", when he talks of the qualities of a "great wine":

qualities of intensity, complexity, rarity and personality; it is then said to have character, typicity, breed, and be full of aromatic savour. A distinction should be made between finesse and breed. A wine may have finesse but not breed if it does not also have the characteristics typical of its origin. An unobtrusive (efface) wine lacks personality; it is ordinary and insignificant. (186)

\section{Physical and spatial metaphors}

It is perhaps a characteristic of human communication that our language is full of metaphors exploiting the physical world we share more transparently. In everyday communication (as opposed to poetry) our metaphors need to be cognate to succeed. Peynaud notes that we use language to attempt to make the imaginary real. He suggests tasters form "a physical image of the wine", making it "feel like a substance with three dimensions". Peynaud identifies a clear orientation among tasters to manifest a wine in structural and spatial terms. Tasters

talk of (wine's) contours and its architecture as though the liquid had a design, a particular surface texture, an internal structure. A wine's ideal form is the sphere, which represents a space in perfect equilibrium. (168)

\section{Sample terms are:}

spherical, round, flat, threadlike, rectilinear, lanky or long-limbed, square, ${ }^{2}$ angular, sharp, pointed, etc. (168)

What makes Peynaud's discourse on wine interesting is that he never attempts to simplify the task he is facing. Not only are tastes ephemeral, and the task of translating taste and smell sensations into words fiendishly difficult, but the wine keeps changing in character as it evolves - both in the glass and in the mouth:

the form that the wine assumes as soon as it is in one's mouth is not static and definitive; it changes as the taste sensations of the wine evolve. (168)

The result is the addition of a dynamic dimension to the description of the taste of wine: 
If the initial roundness remains for a long period the wine is said to be 'long'; if it changes rapidly, the wine is 'short'(168)

51 Also interesting, given contemporary interest in the metaphor of the body, is the anthropomorphic vocabulary used to describe wine in physical terms. Peynaud begins by addressing this issue as a category of "size" and "balance", but the terms are a catalogue of anthropomorphic distinctions. Peynaud cites the following pejorative terms for light or insubstantial wines - "thin, tenuous, slight, narrow, lean, skimpy, puny, gangling, and stunted" - and for full-bodied wines - "stout, thick, heavy, fat, and podgy".

In the end, Peynaud returns to his theme, which involves not so much the size and variety of the vocabulary, but one's knowledge of how and when to apply this vocabulary:

The terminology is vast, but more important than its size is to know how to use it.

(169)

53 It is at this point in his book that Peynaud is drawn to trying to represent wine vocabulary in graphic terms, in its own architectural arrangement. He offers structural models for the vocabulary of wine, placing the vocabulary in a matrix which attempts to pin down descriptive terms' relationships to each other. If matching vocabulary to the taste of an actual wine is elusive, and the tasting competence or physical propensities of tasters is endlessly variable, perhaps the terms themselves can be placed in an objectively valid relationship to each other. Peynaud's own scheme is spatial and orientational, but he cites another which attempts to place a vocabulary of wine terms describing 'balance' in wine in a spatial relationship to each other, as in Fig. 1 below:

It is interesting that only a few of these terms offer analogies with fruits or other substances we conventionally associate with bouquet or aroma (honeyed, bitter, sweetish). They are predominantly anthropomorphic, cast in our own image and, as we see below, often heavily gendered.

\section{Gender and alcohol}

It is noticeable in the diagram below that one of the 3 spectra we are offered is "masculine <-feminine". The descriptions are easily recognised as standard stereotypes, with expressions like "harsh, thick, rough and robust" associated with masculinity, and "fleshy, unctuous, honeyed, soft, supple and cloying" associated with femininity. The social construction of associations between men and women and the drinking of alcohol is addressed by Gurr, who says of Simenon's Maigret series:

In Maigret's Paris, men drink and women don't. Both the women who drink too much do not report a murder. And of the three men who are abnormal because they do not drink, two are murderers ... Only four women are ever described drinking alcohol. One is the landlady (who serves him chartreuse), another is a prostitute whom Maigret buys a drink in exchange for information. The other two (both wealthy) are alcoholics. (1987: 233, 229) 
Fig. 1. A graphic representation of terms relating to balance (after Vedel 1972)

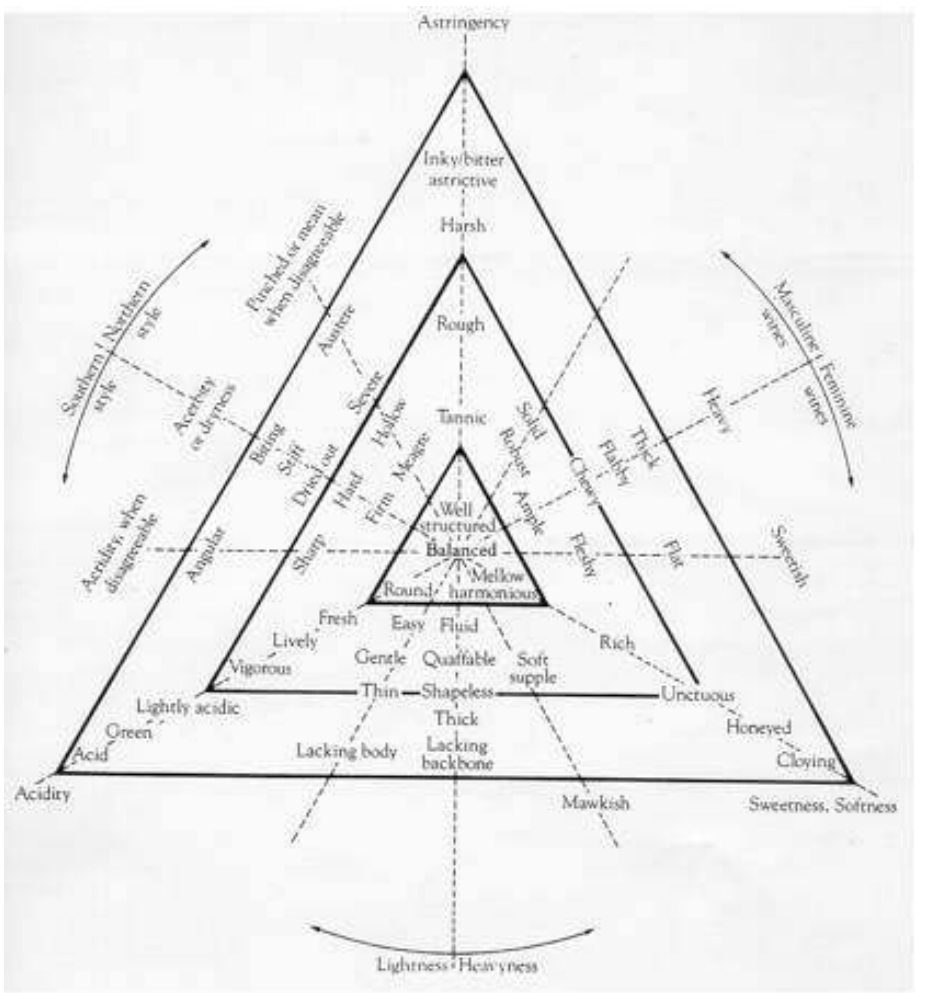

\section{Wine tastings}

Wine tastings are experiences within reach of most readers of this paper; I discussed the language of judgements of taste at the Knowledge and Discourse Conference in a workshop context so participants could experience first hand some of the difficulties of putting smells and tastes into words, and some of the differences people encounter trying to share impressions of a single wine. A participant from mainland China found a New Zealand Sauvignon Blanc - the 1994 Cloudy Bay - to be "sour". This was clearly relative to the kinds of wine she was used to drinking, which were likely mostly to have contained a much higher percentage of residual sugar. In saying "sour", she was making a comment grounded in her cultural context, in which her norm for "wine" would probably be constructed as a "sweet wine" by people more accustomed to European wines, or to a range of wine varietals.

It would be interesting for readers of this paper to seek out opportunities to participate in wine tastings, not only to enjoy the wines (!) but to see how the participants exhibit assumptions of authority or ignorance, loquacity or silence, and certitude or tentativeness. In my experience, more formal wine tastings where the wines are judged and ranked make those on the periphery of the knowledge/disciplinary community loathe to commit themselves verbally, for fear of 'getting it wrong'. Rather than trust their judgement or language, they can be intimidated into copying the language they hear around the table. It may be, as Peynaud suggests (223), that novices at tasting wine find it easier to detect faults than positive qualities in wines, but in a group tasting context they are often loath to make negative comments, for fear of appearing ignorant, 
foolish, deficient - \& of not being accepted into that community. At a recent tasting, the host asked the tasters present to vote for the "better" of 2 wines; after a small number very tentatively raised their hands for wine A, he exclaimed gleefully, but goodhumouredly: "Wrong!". The laughter that greeted this retort belied the tendency at such gatherings to see such tests in terms of right and wrong.

Finally, the most intimidating means of social control available to confirm hierarchy in such gatherings: the rank-order scoring of the wines. In such tastings, the participants are required to rank-order 12 wines, and the scores are collected, collated and an aggregate is produced, resulting in a group rank-order. This procedure can reveal to participants how close they are to the group norm (generally taken to be optimal) but as the scorer reads out the number of nominations for $1^{\text {st }}, 2^{\text {nd }}$ and last ranked wines, it becomes clear how far there has been unanimity or a 'gross disparity' among the palates. One member has periodically asked that associate members and guests have their cards marked, so the ignorance of those on the periphery of the authoritative core membership can be revealed. This type of power/knowledge relation is most common among wine waiters, and anecdotes are legion of their making their clients squirm in embarrassment, and feeling obliged to continue drinking corked or otherwise defective wine. Accounts of such experiences are also for another paper - but readers are welcome to submit any of their own to me.

\section{Conclusion}

In this paper I have focused on a single, but highly influential, book as a case study. I have found a tension throughout Peynaud's book between

- a rhetoric of wine and tasting wine as an art and as a science;

- a sense of the impossibility of pinning down the butterfly of taste in a linguistic aspic, and yet a mission to continue in search of that grail;

- a concern to respect freedom of expression and yet to resist the anarchy of the absence of an agreed comprehensive vocabulary;

- an association of nobility with knowledge and respect for the complexities and nuances of wine, and an association of a dangerous barbarity with the great majority associated with gluttony and the "swilling" of wine, whose satisfaction with mediocre wine Peynaud almost sees as a threat to the civilisation of fine wine appreciation he vaunts and seeks to promote.

The overriding impressions I have of Peynaud's book is its commitment to the cause of oenology, with Peynaud pursuing his educational programme with the systematicity and strategy of the lepidopterist. At a rational level, Peynaud is fully aware of the elusiveness of his linguistic goal; the writer of the Introduction to the English version of Peynaud's book, Michael Broadbent, admits:

A complete and universally accepted scientific analysis, classification and description of smells and tastes, despite a mass of multidisciplinary research and enquiries, appears to defy solution. (1975:2)

61 What I have attempted to show in this paper is that a closer reading of the text reveals classifications, hierarchies, metaphors and constructions of communities of tasters and properties of wine, that cumulatively reveal a particular epistemological orientation to the relationship between language and knowledge. This is the type of orientation to knowledge and discourse that I suggest is not uncommon in any social or academic sphere, and that reflects a need to provide explanations of the unknown that we can 
grasp - literally and linguistically. As the title of the workshop from which this paper was drawn (Bruce, 1999) is meant to suggest, perhaps we cannot escape the paradox in the expression we've borrowed from the French to describe an elusive quality - a certain "je ne sais quoi".

Thanks are due to those participants at the Workshop on "The Taste of Wine", particularly for their enthusiastic participation in the practical phase of the workshop! Thanks especially to Peter Weingart, who encouraged me to write this up into a paper. Much of the material here has come out of re-readings of Peynaud, so I look forward to comments from those participants.

\section{BIBLIOGRAPHY}

Bourdieu, P. 1984. Distinction: A social critique of the judgement of taste. London: Routledge.

Broadbent, M. 1975. Wine Tasting. London: Christie's Wine Publications.

Bruce, N. 1999. "A certain “je ne sais quoi" - the voice of authority in Émile Peynaud's The Taste of Wine". in Barron C. \& N. Bruce (eds.), Proceedings of the 1st International Conference on Knowledge and Discourse, Hong Kong.

Chaptal. 1807. L'art de faire le vin. Paris: Deterville.

Gronow, J. 1993. “What is 'good taste'?”. Social Science Information 32/2, 279-301.

Gurr, L. A. 1987. “Maigret's Paris conserved and distilled”. In Douglas M. (ed.), Constructive drinking: Perspectives on drink from Anthropology. Cambridge: Cambridge University Press, 220-236.

Lupton, D. 1996. Food, the Body and the Self. London: Sage.

Peynaud, E. 1984 [1971]. Connaissance et travail du vin. Paris: Dunod, Trans. as John Wiley \& Sons, New York.

Peynaud, E. 1983. Le goût du vin. Paris: Bordas.

Peynaud, E. 1987. The Taste of Wine. London: Macdonald Orbis, Trans. Michael Schuster.

Robinson, J. (ed.). 1994. The Oxford Companion to Wine. Oxford: Oxford University Press.

Vedel, A. et al. 1972. Essai sur la dégustation des vins. Macon: Société d'édition et d'informations viti-vinicoles.

\section{NOTES}

1. Peynaud does not provide references for de Coquet or Coste.

2. One of British wine critic Clive Coates' favourite descriptors is "four square", meaning solid but uninspiring. 


\section{ABSTRACTS}

This paper is concerned with knowledge and discourse, and how the wine community operates as a "knowledge territory", developing discourses of classification, hierarchy, and authority. The author focuses on the discourse of smell and taste in wine, and the extent to which these tend to be constructed as objective and as having precise linguistic correlates. He looks in particular at the social stratification and construction of wine tastes - and tasters - by Émile Peynaud, an "authority" on wine making and wine chemistry, in his book, The Taste of Wine (1987) [the translation of the 1983 original, Le Goût du vin].

Le présent article s'intéresse à la relation entre savoir et discours, à la façon dont la communauté savante du vin fonctionne comme "territoire de savoir" générant des discours de classification, de hiérarchisation et d'autorité. L'auteur s'attache aux discours spécifiques du bouquet et du goût du vin, ainsi qu'à la manière dont ces derniers tendent à se construire comme objet et à présenter des corrélations linguistiques caractéristiques. Il examine en particulier la stratification sociale et la construction du goût, voire celle des dégustateurs, par Émile Peynaud, autorité reconnue en matière d'élevage et de chimie du vin dans son ouvrage Le Goût du vin (1983).

\section{INDEX}

Mots-clés: bouquet, classification, communauté du vin, dégustation, discours, goût, métaphore, savoir, vocabulaire du vin

Keywords: discourse, knowledge, metaphor, smell, taste, wine community, wine tasting, wine vocabulary

\section{AUTHOR}

\section{NIGEL BRUCE}

Nigel Bruce has taught English in France, Mongolia and Kuwait, and has spent the last twelve years at Hong Kong University, teaching academic communication skills. He currently teaches students of Law, Dentistry, Social Sciences, Arts and Applied Linguistics. His research and development interests are in constructions of knowledge and practice, academic writing and the potential of the Internet for promoting autonomous learning and enriching writing response practices across the academy. njbruce@hkucc.hku.hk 